\title{
Cikkismertetés: Tényleg 10.000 lépést kell tennünk naponta az egészségünkért?
}

\author{
Article review: Do we really need to take 10,000 steps a day for our health?
}

Ismertető: $\quad$ Tarkó Klára $₫$

Szegedi Tudományegyetem, Juhász Gyula Pedagógusképző Kar, Alkalmazott

Egészségtudományi és Egészségfejlesztési Intézet, Szeged

Ismertetett cikk: Hall, K.S., Hyde, E.T., Bassett, D.R. et al. Systematic review of the prospective association of daily step counts with risk of mortality, cardiovascular disease, and dysglycemia. Int J Behav Nutr Phys Act 17, 78 (2020). https://doi.org/10.1186/s12966-020-00978-9

Beküldve: $\quad$ 2020.10.14.

doi: $\quad$ 10.24365/ef.v61i4.641

Kulcsszavak: fizikai aktivitás; séta; diabétesz; prevenció; gyorsulásmérő; fizikai aktivitásra vonatkozó iránymutatások; népegészségügy

Keywords: physical activity; walking; diabetes; prevention; accelerometer; physical activity guidelines; public health

\section{HÁTTÉR}

A megtett napi lépések számának nyomon követése a tapasztalatok alapján sikeres, fizikai aktivitásra motiváló tényezőnek bizonyult a felnőttek körében. A lépésszámláló-mobilalkalmazások és okoseszközök széleskörű elterjedése a „napi lépésszám” mutatót az ajánlott napi séta mérőszámává és elérendő céljává tették, amely alkalmas lehet a mozgásra vonatkozó népegészségügyi ajánlások közvetítő eszközeként is. De mennyi is az annyi, hány lépés vezet a jobb egészségi állapot elérése és megőrzése felé? A jelen tanulmány pontosan erre keresi a választ, megvizsgálva, hogy milyen összefüggés mutatható ki az egészségünk szempontjából hatékony napi lépésszám és az összes halálozás alakulása között, valamint kiemelten vizsgálja annak a szív-érrendszeri megbetegedésekkel és halálozásokkal, valamint a kóros vércukorszinttel való ezirányú összefüggéseit.

A szerzők szisztematikus áttekintést végeztek a Medline, az Embase, a CINAHL és a Cochrane Library adatbázisaiban a kezdetektől 2019. augusztus 1-ig bezárólag. Azokat a tanulmányokat dolgozták fel, amelyek eleget tettek a következő kritériumoknak: követéses vizsgálat, az egészségmutatókat a vizsgálat kezdetén és az azt követő időpontokban is mérték; az eszközzel mért napi lépésszám volt a független változó; beszámoltak az összes halálozásra, a szív-érrendszeri megbetegedésre és halálozásra és/vagy kóros vércukorszintre gyakorolt hatásokról; 18 év feletti felnőttek vettek részt a vizsgálatokban; nem beteg populációkra irányult; a cikk angolul íródott.

\section{EREDMÉNYEK}

A keresés 17 tanulmányt eredményezett, több mint 30000 felnőtt résztvevő adataival. Öt tanulmány számolt be az összes halálozás alakulásáról (követési idő 4-10 év), négy a kardiovaszkuláris kockázatról vagy eseményekről ( 6 hónap és 6 év között), nyolc pedig a kóros vércukorszint megjelenéséről (3 hónap és 5 év között).

$\mathrm{Az}$ áttekintett tanulmányok összevont elemzése bizonyítja, hogy a napi lépésszám növelése kedvező hatású az egészségre: több lépés naponta alacso- 
nyabb összhalálozással (csökkenés mértéke 6-36\%), valamint szív-érrendszeri betegséggel és halálozással (5-12\%) jár. Még alacsony lépésszám esetén is 1000-el növelve a lépésszámot tovább csökkent a kockázat. Ezek az összefüggések igazak voltak bármelyik korcsoportra, nemre, és testtömeg-kategóriára.

\section{KÖVETKEZTETÉSEK}

A kóros vércukorszintre gyakorolt hatást vizsgáló tanulmányok ellentmondásos következtetésekre jutottak, részben a biomarker eredmények, az elemzési megközelítések és a vizsgált csoportok jellemzőinek eltérései miatt.
A követéses vizsgálatokból nyert bizonyítékok azonban következetesen alátámasztják, hogy minden, napi 1000 lépésszám növekedés csökkentheti a felnőttek összes halálozásának, valamint szívérrendszeri megbetegedésének és halálozásának kockázatát, és hogy a kedvező egészséghatások már 10000 lépés alatt jelentkeznek. A lépésszámmennyiség és az elért eredmény közötti kapcsolat mintázata azonban még nem tisztázott. Továbbra sem állnak rendelkezésre adatok annak megállapításához, hogy mi az általános pozitív egészséghatások eléréséhez szükséges napi lépésszám alsó küszöbértéke.

\section{TANULSÁGOK A HAZAI SZAKEMBEREK SZÁMÁRA}

Sokan tartjuk jó mókának a lépésszámláló alkalmazások és okoseszközök használatát, főként, ha azok meg is dicsérnek bennünket a teljesítményünkért és buzdítanak a továbbfejlődésre. A közösségi megosztások lehetővé teszik, hogy összevessük teljesítményünket másokéval, de akár önmagunk „legyőzésére” is használhatjuk, mindig új célokat tűzve magunk elé. Mindenki jól ismeri a 10000 napi lépésre vonatkozó általános ajánlást. Vannak, akiket elbizonytalanít ez a magas szám és úgy gondolják, nincs naponta több órájuk ilyesmire. Nekik szólnak a jelen cikkben bemutatott eredmények, melyek jelzik, hogy már az ennél kevesebb lépésszám is jótékony hatással van az egészségünkre. Néha a kevesebb több, már azzal sokat tehetnek az egészségükért, ha gyalog járnak munkába, bevásárolni, a lift helyett a lépcsőt használják, este tesznek egy rövid sétát, vagy megsétáltatják a kutyát. A lépésszámláló 'kütyü' legyen értünk és ne mi őérte, tehát arra használjuk, hogy rácsodálkozzunk hány lépést is sikerült megtennünk egyszerű életmódváltoztatással ahelyett, hogy a lépésszámlálónkat figyelve vonszoljuk magunkat a bűvös 10000 lépés felé, elveszítve a mozgás felett érzett örömet. Szükség van olyan célzott vizsgálatokra, amelyek korra, nemre, egészségi állapotra vonatkozóan mutatják ki a már jótékony hatású lépésszám küszöböket, jó érzést keltve azokban is, akik nem tudnak univerzális lépésteljesítményt felmutatni. 